\title{
GAMBARAN PENGETAHUAN DAN SIKAP BIDAN \\ DI RSU PROF. DR. R. D. KANDOU MANADO TENTANG INISIASI MENYUSU DINI
}

\author{
${ }^{1}$ Fadhillawatie Maanaiya \\ ${ }^{2}$ Maria Loho \\ ${ }^{2}$ Linda Mamengko
}

\author{
${ }^{1}$ Kandidat Skripsi Fakultas Kedokteran Universitas Sam Ratulangi Manado \\ ${ }^{2}$ Bagian Obstetri dan Ginekologi Fakultas Kedokteran Universitas Sam Ratulangi Manado \\ Email: FMaanaiya11_193@yahoo.com
}

\begin{abstract}
Early Initiation of Breastfeeding (IMD) is the process of feeding the baby immediately after birth, which has important benefits such as support the sustainability of exclusive breastfeeding and potentially reduce IMR and MMR. Based on data by RISKESDAS 2013, the percentage of IMD implementation in Indonesia is only $34.5 \%$ and in North Sulawesi is only $29 \%$. Midwives are recognized as professionals who work as female partners including help the mothers in initiating breastfeeding. Therefore midwives are expected to have a good knowledge and a positive attitude towards the IMD so the implementation may increase. This study aims to measure the knowledge and attitude of RSU Prof. Dr. R. D. Kandou Manado midwives toward early initiation of breastfeeding in 2014. This is a cross-sectional study using questionnaire administered to midwives in RSU Prof. Dr. R. D. Kandou Manado. As a results from 62 respondents, 41 respondents (66.1\%) had a good knowledge on IMD, 14 respondents (22.6\%) with moderate knowledge, 7 respondents (11.3\%) with poor knowledge and all respondents (100 \%) had a positive attitude towards the IMD. Most of midwife with a good knowledge is those who with age 36-40 years, Bachelor of Midwifery (S-I) and has been working for 6-10 years old.
\end{abstract}

Keywords: knowledge, attitude, midwife, early breastfeeding initiation, IMD

\begin{abstract}
Abstrak: Inisiasi Menyusu Dini (IMD) adalah proses bayi menyusu segera setelah dilahirkan, yang memiliki manfaat penting diantaranya yaitu menunjang keberlangsungan ASI ekslusif serta berpotensi menurunkan AKB dan AKI. Berdasarkan data oleh RISKESDAS 2013, persentase pelaksanaan IMD di Indonesia baru sebesar 34,5\% dan di Sulawesi Utara baru sebesar $29 \%$. Bidan diakui sebagai tenaga profesional yang bekerja sebagai mitra perempuan termasuk membantu ibu dalam memulai pemberian ASI. Oleh karena itu bidan diharapkan memiliki pengetahuan yang baik serta sikap yang positif terhadap IMD sehingga pelaksanaan IMD dapat meningkat. Tujuan penelitian ini untuk mengetahui pengetahuan dan sikap bidan di RSU Prof. Dr. R. D. Kandou Manado tentang IMD tahun 2014. Penelitian ini dilakukan dengan desain penelitian cross-sectional menggunakan kuesioner kepada bidan di RSU Prof. Dr. R. D. Kandou Manado. Hasil penelitian dari 62 responden, didapatkan bahwa 41 responden $(66,1 \%)$ telah memiliki pengetahuan yang baik tentang IMD, 14 responden (22,6\%) berpengetahuan cukup, 7 responden $(11,3 \%)$ berpengetahuan kurang serta seluruh responden (100\%) memiliki sikap positif terhadap IMD. Mayoritas bidan yang berpengetahuan baik ialah bidan dengan umur 36-40 tahun, berpendidikan S-I Kebidanan dan lama kerja 6-10 tahun.
\end{abstract}

Kata kunci: pengetahuan, sikap, bidan, inisiasi menyusu dini, IMD 
Inisiasi Menyusu Dini adalah proses bayi menyusu segera setelah dilahirkan, di mana bayi dibiarkan mencari puting susu ibunya sendiri (tidak disodorkan ke puting susu). IMD adalah proses membiarkan bayi dengan nalurinya sendiri dapat menyusu segera dalam satu jam pertama setelah lahir, bersamaan dengan kontak kulit antara bayi dengan kulit ibu. Bayi dibiarkan setidaknya selama satu jam di dada ibu, sampai dia menyusu sendiri. ${ }^{1}$

Menyusui sejak dini mempunyai dampak yang positif. Air susu yang pertama kali dikeluarkan setelah melahirkan yaitu kolostrum, mengandung protein yang lebih tinggi (sebagian besar immunoglobulin) serta kandungan gula yang lebih rendah dibandingkan air susu yang diproduksi kemudian. ${ }^{2}$ Menurut UNICEF, IMD dapat mengurangi kematian neonatal sekitar $20 \% .^{3}$ IMD berperan dalam merangsang produksi ASI. ${ }^{4,5}$ Hal ini akan sangat membantu dalam keberlangsungan pemberian ASI eksklusif (ASI saja) dan lama menyusui. Dengan demikian, bayi akan terpenuhi kebutuhannya hingga usia 2 tahun, dan mencegah anak kurang gizi. ${ }^{1}$

Sedangkan bagi ibu, menyusui dapat mengurangi morbiditas dan mortalitas karena proses menyusui akan memfasilitasi pelepasan oksitosin, yang membantu kontraksi uterus sehingga mengurangi perdarahan pasca melahirkan (postpartum). ${ }^{4,6}$

Bidan diakui sebagai tenaga professional yang bekerja sebagai mitra perempuan untuk memberi dukungan, asuhan, dan nasehat selama hamil hingga masa nifas, termasuk memberikan penjelasan tentang hal-hal yang mempercepat pulihnya kesehatan ibu dan membantu ibu untuk memulai pemberian ASI. ${ }^{7,8}$

Berdasarkan data dari RISKESDAS 2013, persentase pelaksanaan IMD di Indonesia baru sebesar 34,5\% dengan persentasi di Sulawesi Utara baru sebesar $29 \%{ }^{6}$

Pengetahuan merupakan salah satu faktor yang penting dalam mempengaruhi perilaku seseorang. Sementara sikap merupakan kesiapan atau kesediaan untuk bertindak, yang menjadi predisposisi tindakan suatu perilaku. ${ }^{9}$ Maka perilaku dalam hal ini pelaksanaan IMD oleh bidan tentunya tak luput didasari oleh pengetahuan serta sikap dari bidan itu sendiri.

\section{METODE PENELITIAN}

Penelitian ini dilakukan dengan desain penelitian cross-sectional menggunakan kuesioner. Subjek penelitian yaitu seluruh bidan yang ada dan bekerja di bagian Obstetri dan Ginekologi FK UNSRAT / RSU Prof. Dr. R. D. Kandou Manado, dengan kriteria eksklusi yaitu bidan yang sementara cuti dan yang tidak bersedia menjadi responden. Penelitian dilakukan dari bulan November sampai Desember 2014. Variabel penelitian terdiri dari variable terikat yaitu pengetahuan bidan dan sikap bidan tentang IMD, serta variabel bebas yaitu umur, pendidikan terakhir, dan lama kerja.

Hasil skor pengetahuan dibagi menjadi tiga kategori penilaian yaitu baik bila diperoleh jawaban benar 76-100\%, cukup bila diperoleh jawaban benar 56-75\%, dan kurang bila diperoleh jawaban benar $<56 \%$. Sedangkan hasil skor sikap dibagi menjadi dua yaitu positif bila responden memiliki jumlah skor 10-24 dan negatif bila responden memiliki jumlah skor 25-40.

\section{BAHASAN DAN HASIL PENELITIAN}

Dari 67 bidan yang terdata di RSU Prof. Dr. R. D. Kandou Manado pada bulan November sampai Desember 2014, didapatkan sebanyak 62 responden yang memenuhi kriteria inklusi sebagai subjek penelitian.

Berdasarkan karakteristik responden sesuai pada Gambar 1, didapatkan bahwa jumlah responden terbanyak berada pada kelompok umur 31-35 tahun, berpendidikan terakhir D-III Kebidanan dan lama kerja $>10$ tahun.

Untuk pengetahuan responden tentang inisiasi menyusu dini dapat dilihat pada Tabel 1, bahwa sebagian besar responden dalam penelitian ini telah memiliki 
pengetahuan yang baik tentang inisiasi menyusu dini yaitu sebanyak 41 responden (66,1\%), diikuti 14 responden (22,6\%) memiliki tingkat pengetahuan cukup, dan 7 responden (11,3\%) memiliki tingkat pengetahuan kurang.
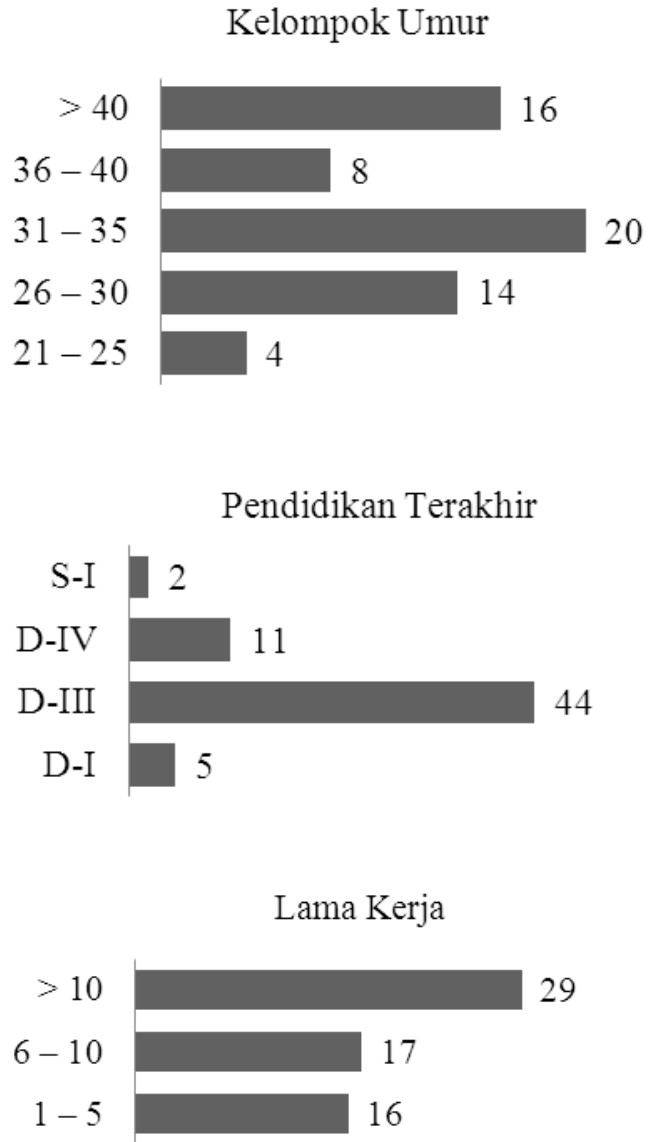

Gambar 1. Karakteristik Responden

Tabel 1. Pengetahuan tentang IMD

\begin{tabular}{ccc}
\hline Pengetahuan & $\mathrm{n}$ & $\%$ \\
\hline Kurang & 7 & 11.3 \\
Cukup & 14 & 22.6 \\
Baik & 41 & 66.1 \\
\hline Total & 62 & 100 \\
\hline
\end{tabular}

Ini sesuai dengan penelitian sebelumnya oleh Natalina (2010) ${ }^{10}$ yang berjudul Pengetahuan dan Sikap Bidan Tentang Inisiasi Menyusu Dini Di Wilayah
Kerja Puskesmas Medan Timur Tahun 2010, bahwa pengetahuan responden sebagian besar menunjukkan berpengetahuan baik tentang inisiasi menyusu dini (86,7 \%).

Dari 62 responden, seluruhnya (100\%) menunjukkan sikap yang positif tentang inisiasi menyusu dini. (Tabel 2)

Tabel 2. Sikap tentang IMD

\begin{tabular}{ccc}
\hline Sikap & $\mathrm{n}$ & $\%$ \\
\hline Positif & 62 & 100 \\
Negatif & 0 & 0 \\
\hline Total & 62 & 100 \\
\hline
\end{tabular}

Hasil ini sesuai dengan penelitian yang dilakukan oleh Natalina $(2010)^{10}$ bahwa seluruh bidan yang menjadi respondennya memiliki sikap positif tentang inisiasi menyusu dini (100\%). Sikap yang positif terhadap inisiasi menyusu dini berarti bahwa bidan sudah memiliki reaksi atau respon yang mendukung namun belum dinyatakan dalam suatu tindakan. ${ }^{11}$

Selanjutnya distribusi pengetahuan responden dianalisis berdasarkan variable bebasnya. Tabel 3 menunjukkan bahwa kelompok umur 36-40 tahun merupakan responden terbanyak yang memiliki pengetahuan yang baik (75\%). Hal ini sesuai dengan penelitian oleh Sari $(2011)^{12}$ dimana responden yang berpengetahuan baik terdapat pada responden yang berumur 30 - 40 tahun (52\%).

Sesuai pendapat Notoatmodjo (2010) dalam Sakamole (2014) ${ }^{13}$ bahwa semakin tua umur seseorang maka pengalaman akan semakin banyak, dan pengalaman merupakan salah satu faktor yang mempengaruhi pengetahuan seseorang. Bertambahnya umur seseorang dapat berpengaruh pada peningkatan pengetahuan yang diperoleh, akan tetapi pada umur tertentu atau menjelang usia lanjut, kemampuan dalam menerima dan mengingat suatu pengetahuan akan berkurang. ${ }^{14}$ 
Tabel 3. Pengetahuan berdasarkan umur

\begin{tabular}{ccccc}
\hline $\begin{array}{c}\text { Kelompok } \\
\text { umur } \\
\text { (tahun) }\end{array}$ & $\sum(\mathrm{n})$ & \multicolumn{3}{c}{ Pengetahuan } \\
\cline { 3 - 5 } & & Kurang & Cukup & Baik \\
\hline $21-25$ & 4 & 1 & 1 & 2 \\
& & $25 \%$ & $25 \%$ & $50 \%$ \\
$26-30$ & 14 & 2 & 3 & 9 \\
& & $14.3 \%$ & $21.4 \%$ & $64.3 \%$ \\
$31-35$ & 20 & 1 & 6 & 13 \\
& & $5 \%$ & $30 \%$ & $65 \%$ \\
$36-40$ & 8 & 1 & 1 & 6 \\
& & $12.5 \%$ & $12.5 \%$ & $75 \%$ \\
$>40$ & 16 & 2 & 3 & 11 \\
& & $12.5 \%$ & 18.75 & 68.75 \\
& & & $\%$ & $\%$ \\
\hline \multirow{2}{*}{ Total } & 62 & 7 & 14 & 41 \\
& $100 \%$ & $11.3 \%$ & $22.6 \%$ & $66.1 \%$ \\
\hline
\end{tabular}

Pada Tabel 4, responden yang memiliki pengetahuan yang baik ialah responden dengan tingkat pendidikan terakhir S-I Kebidanan (100\%). Sesuai pendapat oleh Pro-Health (2009) dalam Puteri (2013) ${ }^{11}$, semakin tinggi pendidikan seseorang semakin mudah orang tersebut untuk menerima informasi.

Tabel 4. Pengetahuan berdasarkan tingkat pendidikan terakhir

\begin{tabular}{ccccc}
\hline \multirow{2}{*}{$\begin{array}{c}\text { Pendidikan } \\
\text { terakhir }\end{array}$} & $\sum(\mathrm{n})$ & \multicolumn{3}{c}{ Pengetahuan } \\
\cline { 3 - 5 } & & Kurang & Cukup & Baik \\
\hline \multirow{2}{*}{ D-I } & 5 & 1 & 1 & 3 \\
& & $20 \%$ & $20 \%$ & $60 \%$ \\
D-III & 44 & 4 & 11 & 29 \\
& & $9.1 \%$ & $25 \%$ & $65.9 \%$ \\
D-IV & 11 & 2 & 2 & 7 \\
& & $18.2 \%$ & $18.2 \%$ & $63.6 \%$ \\
S-I & 2 & 0 & 0 & 2 \\
& & $0 \%$ & $0 \%$ & $100 \%$ \\
\hline \multirow{2}{*}{ Total } & 62 & 7 & 14 & 41 \\
& $100 \%$ & $11.3 \%$ & $22.6 \%$ & $66.1 \%$ \\
\hline
\end{tabular}

Dengan pendidikan tinggi maka seseorang akan cenderung untuk mendapatkan informasi, baik dari orang lain maupun dari media massa. Semakin banyak informasi yang masuk semakin banyak pula pengetahuan yang didapat tentang kesehatan.

Yang terakhir untuk lama kerja, Tabel 5 menunjukkan bahwa responden dengan lama kerja 6-10 tahun memiliki pengetahuan yang baik (76,5\%). Hal ini sesuai dengan penelitian oleh Sari (2011) ${ }^{12}$ dimana mayoritas respondennya yang berpengetahuan baik terdapat pada responden dengan lama kerja 5 - 15 tahun (52\%).

Tabel 5. Pengetahuan berdasarkan lama kerja

\begin{tabular}{ccccc}
\hline \multirow{2}{*}{$\begin{array}{c}\text { Lama } \\
\text { kerja } \\
\text { tahun) }\end{array}$} & $\sum(\mathrm{n})$ & \multicolumn{3}{c}{ Pengetahuan } \\
\cline { 3 - 5 } & & Kurang & Cukup & Baik \\
\hline $1-5$ & 16 & 3 & 4 & 9 \\
& & $18.75 \%$ & $25 \%$ & $56.25 \%$ \\
$6-10$ & 17 & 1 & 3 & 13 \\
& & $5.9 \%$ & $17.6 \%$ & $76.5 \%$ \\
$>10$ & 29 & 3 & 7 & 19 \\
& & $10.3 \%$ & $24.1 \%$ & $65.5 \%$ \\
\hline \multirow{2}{*}{ Total } & 62 & 7 & 14 & 41 \\
& $100 \%$ & $11.3 \%$ & $22.6 \%$ & $66.1 \%$ \\
\hline
\end{tabular}

Sesuai pendapat Anderson (1994) dalam Hajrah (2012) ${ }^{15}$, seseorang yang sudah lama bekerja mempunyai wawasan yang lebih luas dan pengalaman yang banyak. Namun Robin (1996) dalam Hajrah (2012) ${ }^{15}$ mengatakan tidak ada jaminan bahwa yang lebih lama bekerja dapat dikatakan lebih produktif, justru kinerja makin menurun akibat kurangnya rangsangan sejalan dengan makin tuanya usia.

\section{SIMPULAN}

Pada penelitian ini dapat disimpulkan bahwa secara keseluruhan sebagian besar responden yaitu bidan di RSU Prof. Dr. R. D. Kandou Manado telah memiliki pengetahuan yang baik tentang inisiasi menyusu dini, yaitu sebesar 66,1\% (41 responden), dan sisanya sebesar 22,6\% (14 
responden) berpengetahuan cukup, serta masih ada $11,3 \% \quad$ (7 responden) berpengetahuan kurang.

Sikap responden tentang inisiasi menyusu dini secara keseluruhan berada pada kategori positif, yaitu sebesar $100 \%$ (62 responden).

Mayoritas responden berpengetahuan baik berada pada kelompok umur 36-40 tahun sebesar $75 \%$ (6 responden), pendidikan terakhir S-I Kebidanan sebesar $100 \%$ (2 responden), dan pada responden dengan lama kerja 6-10 tahun sebesar $76,5 \%$ (13 responden).

\section{SARAN}

1. Tenaga Kesehatan

Diharapkan bidan untuk lebih meningkatkan pemahaman dan informasi mengenai inisiasi menyusu dini melalui media cetak maupun elektronik, mengikuti pelatihanpelatihan tentang inisiasi menyusu dini serta bukan hanya sekedar mengetahui tetapi melaksanakan inisiasi menyusu dini di tempat praktik. Dalam hal pelaksanaannya diharapkan agar bidan melaksanakannya sesuai dengan tata cara pelaksanaan inisiasi menyusu dini yang tepat, bukan hanya mengenalkan puting ibu pada bayi seperti yang banyak terjadi saat ini.

2. Rumah Sakit

Diharapkan untuk dapat memperbanyak informasi dan pelatihan kepada tenaga kesehatannya tentang inisiasi menyusu dini serta lebih mempertegas kebijakan pelaksanaan inisiasi menyusu dini.

3. Peneliti Lanjut

Untuk penelitian selanjutnya dapat melanjutkan secara lebih spesifik mengenai inisiasi menyusu dini ini yakni dengan meneliti perilaku bidan dalam menerapkan inisiasi menyusu dini.

\section{DAFTAR PUSTAKA}

1. Departemen Kesehatan RI Direktorat Jenderal Bina Kesehatan Masyarakat. Paket Modul Kegiatan - Inisiasi Menyusu Dini (IMD) dan ASI
Eksklusif 6 Bulan. Jakarta: Departemen Kesehatan; 2008.

2. Heffner LJ, Schust DJ. At a Glance Sistem Reproduksi. Jakarta: Erlangga; 2008.

3. UNICEF. World Breasfeeding Week 2010. [Online].; $2010 \quad$ [cited 2014 September 22. Available from: http://worldbreastfeedingweek.org/20 10/pdf/wbw2010los-unicef.pdf.

4. Statistics Indonesia (Badan Pusat Statistik-BPS), National Population and Family Planning Board (BKKBN), and Kementerian Kesehatan (Kemenkes-MOH), and ICF International. Indonesia Demographic and Health Survey 2012. Jakarta: BPS, BKKBN, Kemenkes, and ICF International; 2013.

5. UNICEF. UNICEF Mozambique - Child Survival - Promoting initiation of breastfeeding in the first hour after birth can help saving children's lives. [Online].; $2007 \quad$ [cited 2014 September 22. Available from: http://www.unicef.org/mozambique/c hild_survival_3727.html.

6. Badan Penelitian dan Pengembangan Kesehatan Kementerian Kesehatan RI. Riset Kesehatan Dasar 2013. Jakarta; 2013.

7. Ikatan Bidan Indonesia \& Asosiasi Institusi Pendidikan Kebidanan Indonesia. Standar Nasional Pendidikan Profesi Bidan.; 2012.

8. Syafrudin, Hamidah. Kebidanan Komunitas. Ester M, Wahyuningsih E, editors. Jakarta: EGC; 2009.

9. Maulana HDJ. Promosi Kesehatan. Yudha EK, editor. Jakarta: EGC; 2009.

10. Natalina S. Pengetahuan dan Sikap Bidan Tentang Inisiasi Menyusu Dini di Wilayah Kerja Puskesmas Medan Timur Tahun 2010. Skripsi. Medan: Universitas Sumatera Utara, Fakultas Keperawatan; 2010.

11. Puteri I. Pengaruh Tingkat Pengetahuan Dan Sikap Bidan Tentang Inisiasi Menyusu Dini (IMD) Dengan Penerapan Inisiasi Menyusu Dini Di Puskesmas Kota Surakarta. Thesis. Surakarta: Universita Sebelas Maret, Pascasarjana; 2013.

12. Sari MD. Hubungan Pengetahuan Dan 
Sikap Bidan Praktek Swasta Tentang Inisiasi Menyusu Dini Di Wilayah Kerja Puskesmas Tanjung Morawa Kecamatan Tanjung Morawa. Skripsi. Universitas Sumatera Utara, Program D-IV Bidan Pendidik Fakultas Keperawatan; 2011.

13. Sakamole S. Pengetahuan Ibu Hamil Tentang Kontrasepsi di Bagian Obstetri dan Ginekologi BLU RSUP Prof. dr. R. D. Kandou Manado. Skripsi. Manado: Universitas Sam Ratulangi, Fakultas Kedokteran; 2014.
14. Wibowo AT. Tingkat Pengetahuan Ibu Tentang Cara Menyusui yang Baik dan Benar di Puskesmas Padang Bulan Pada Tahun 2011. Skripsi. Medan: Universitas Sumatera Utara, Fakultas Kedokteran; 2011.

15. Hajrah. Faktor-faktor Yang Berhubungan dengan Perilaku Bidan dalam Pelaksanaan Inisiasi Menyusu Dini (IMD) di Kabupaten Berau. Depok: Universitas Indonesia, Fakultas Kesehatan Masyarakat; 2012. 